\title{
Thermal studies on chromium(II) salts: part 2
}

\begin{abstract}
The thermal behavior of $\mathrm{Cr}(\mathrm{pn}) 3 \mathrm{Br} 2 \cdot 2 \mathrm{H} 2 \mathrm{O}, \mathrm{Cr}(\mathrm{pn}) 3 \mathrm{Cl} 2 \cdot 2 \mathrm{H} 2 \mathrm{O}, \mathrm{Cr}(\mathrm{pn}) 3 \mathrm{SO} 4, \mathrm{Cr}(\mathrm{dien}) 2 \mathrm{Br} 2$, $\mathrm{Cr}$ (dien)2Cl2, $\mathrm{Cr}$ (dien) $\mathrm{Cl} 2$ and $\mathrm{Cr}$ (dien)Br2 was investigated using TG and DSC under nitrogen atmosphere. The thermograms are interpreted and the enthalpies of dissociation are calculated where possible.
\end{abstract}

Keyword: Chromium(II); Chromium(II) amines; Chromium(II) thermal behavior 